FIU Law Review

Fall 2010

\title{
Is Perception Reality?: An Argument Against the Use of Rule 403 for the Exclusion of Eyewitness Identification Expert Testimony
}

Chelsea Moore

Follow this and additional works at: https://ecollections.law.fiu.edu/lawreview

Part of the Other Law Commons

Online ISSN: 2643-7759

\section{Recommended Citation}

Chelsea Moore, Is Perception Reality?: An Argument Against the Use of Rule 403 for the Exclusion of Eyewitness Identification Expert Testimony, 6 FIU L. Rev. 163 (2010).

DOI: https://dx.doi.org/10.25148/lawrev.6.1.11

This Article is brought to you for free and open access by eCollections. It has been accepted for inclusion in FIU Law Review by an authorized editor of eCollections. For more information, please contact lisdavis@fiu.edu. 


\title{
IS PERCEPTION REALITY?: AN ARGUMENT AGAINST THE USE OF RULE 403 FOR THE EXCLUSION OF EYEWITNESS IDENTIFICATION EXPERT TESTIMONY
}

\author{
Chelsea Moore*
}

"But as an expert witness I try to make sure that two victims do not emerge from this crime, that an innocent person is not put behind bars while a guilty person is allowed to go free.",

\section{INTRODUCTION}

DNA evidence has been used to exonerate almost two hundred individuals since 1989; of those two hundred people, approximately seventy-five percent were convicted based on evidence including inaccurate eyewitness identifications. $^{2}$

Imagine being tried and convicted based on an eyewitness testimony, a piece of evidence that scientific studies since 1923 have shown to be both unreliable and inaccurate. ${ }^{3}$ Now imagine that expert testimony regarding the inaccuracy of eyewitness identifications is inadmissible at trial due to the historic role that eyewitness testimony has played in the conviction of countless individuals, when this expert

* J.D., 2011, Florida International University College of Law. I would like to thank the following: Professor Howard M. Wasserman, for his guidance and assistance from the beginning; Professor Kerri L. Stone, for her encouragement and friendship; my family, especially my mom, Leith, for their continuous love and support.

1 Elizabeth Loftus \& Katherine Ketcham, Witness for The Defense: The ACCUSED, THE EYEWITNESS, AND THE EXPERT 72 (1991) [hereinafter LofTus \& KeTCHAM, WITNESS FOR THE DEFENSE].

2 The Justice Project, Eyewitness identification: A Policy Review 2 (2009), available at http://www.psychology.iastate.edu/ glwells/The_Justice\%20Project_Eyewitness_Identification_\%20A_Policy_Review.pdf.

3 Robert J. Hallisey, Experts on Eyewitness Testimony in Court- A Short Historical Perspective, 39 How. L.J. 237, 242 (1995). The questioning of eyewitness identification has also been dated back to 1908 when Hugo Munsterberg wrote, On the Witness Stand. He recognized that eyewitness evidence was much more inaccurate as generally thought. THE JUSTICE PROJECT, supra note 2, at 5. 
opinion may have been the difference between a verdict of "guilty" and "not guilty."

Take the incredulous case of eyewitness identifications leading to the arrest of Sergeant Timothy Hennis. Hennis was accused of the gruesome murder of a mother and her children. ${ }^{4}$ There was no physical evidence and no motive, and the entire case hinged on two eyewitness testimonies. ${ }^{5}$ Dr. Elizabeth Loftus commented that these testimonies were "two of the flimsiest eyewitness accounts" she had ever heard. ${ }^{6}$ Hennis was convicted of the murders and sentenced to death in 1986. The Supreme Court of North Carolina reversed and granted Hennis a new trial in 1988, and, in its discussion, the court recognized the unreliability of the eyewitness testimonies. ${ }^{8}$ The first witness revised his impression of the stature and build of the man he claimed to have seen. Due to his revision, the court held that the testimony was overtly tenuous. ${ }^{9}$ The second witness originally stated that she had not seen anyone. ${ }^{10}$ Therefore, her testimony stating that she had seen the defendant was tentative at best. ${ }^{11}$ After a new trial, this innocent man was acquitted and released, but he could never be compensated for the years he spent on death row, away from his family and friends. Perhaps if an expert on eyewitness identification had been introduced in his first trial this travesty of justice would not have occurred.

Over 75,000 people a year become criminal defendants on the basis of eyewitness identification testimony. ${ }^{12}$ Erroneous eyewitness identification is one of the most frequent causes of mistaken convictions in the United States. ${ }^{13}$ One 1996 study found that twenty-eight convictions based upon eyewitness identifications have been overturned as a result of DNA evidence, and another study stated that mistaken eyewitness identifications caused more than sixty percent of

4 Major Joshua M. Toman, Time to Kill: Euthanizing the Requirement for Presidential Approval of Military Death Sentences to Restore Finality of Legal Review, 195 MIL. L. REV. 1, 64 (2008).

State v. Hennis, 372 S.E.2d 523, 525 (N.C. 1988).

LOFTUS \& KETCHAM, WITNESS FOR THE DEFENSE, supra note 1, at 114.

Id. at 109.

Hennis, 372 S.E.2d at 525 .

Id.

Id.

Id.

12 Richard S. Schmechel et al., Beyond the Ken? Testing Jurors' Understanding of Eyewitness Reliability Evidence, 46 JuRIMETRICS J. 177, 178 (2006) (citing Press Release, Nat'l Sci. Found., False Identification: New Research Seeks to Inoculate Eyewitnesses Against Errors (Jan. 3, 1997), available at http://www.nsf.gov/pubs/stis1997/pr971/ pr971.txt).

13 Margery Malkin Koosed, The Proposed Innocence Protection Act Won't - Unless It Also Curbs Mistaken Eyewitness Identifications, 63 OHIO ST. L.J. 263, 263 (2002). 
the wrongful convictions that were studied. ${ }^{14}$ As part of an effort to curb the overwhelming effect that eyewitness testimony has on the jury, defense attorneys have increasingly been relying on experts to lessen that impact. ${ }^{15}$

"Our criminal justice system is not foolproof; it fails more often than it is comfortable to contemplate." ${ }^{\prime 16}$ There are countless documented cases where eyewitness identification proved to be wrong. In one study, out of eighty-six defendants who had been sentenced to death but later exonerated because of other strong evidence, fifty-four percent of those cases involved eyewitness testimony, and in thirtyeight percent of the cases, eyewitness testimony was the only evidence against the defendant. ${ }^{17}$

One example of eyewitness identification causing injustice is the case of Isadore Zimmerman. Zimmerman was tried and convicted for the murder of a New York City patrolman during a robbery in $1937 .{ }^{18}$ After he was given his last meal and prepared for the electric chair, a guard came in to announce that his sentence had been reduced to life in prison. ${ }^{19}$ After being in prison for twenty-four years, new advanced laboratory techniques were used to prove that Zimmerman could not have committed the crime, and he was subsequently released. ${ }^{20}$

Most studies suggest that eyewitness accounts are not as reliable as often believed. Despite this, few courts have recognized the value of experts testifying on the subject, even when the Federal Rules of Evidence appear to allow such testimony as evidence. Rejection of this sort of testimony based on Rule 403 is attributable to courts' concern that the expert, instead of the jury, will make the credibility determination of the eyewitness. ${ }^{21}$ Though the jury should make the ultimate credibility determination, experts informing the jury on the misconceptions of the reliability of the eyewitness would enhance the jury's knowledge, help guide the jury in finding the relevant facts in a more informed way, and guide the jury to properly weigh the eyewitness testimony. ${ }^{22}$

14 John P. Rutledge, They All Look Alike: The Inaccuracy of Cross-Racial Identifications, 28 AM. J. CRIM. L. 207, 209 (2001).

15 United States v. Smith, 621 F. Supp. 2d 1207, 1210 (M.D. Ala. 2009).

16 Loftus \& KetCHAm, Witness FOR THE DeFEnSE, supra note 1 , at 11.

17 The Justice PROJECT, supra note 2, at 19.

18 LOFTUS \& KETCHAM, WITNESS FOR THE DEFENSE, supra note 1, at 11.

19 Id.

20 Id. (stating that in 1983, forty-four years after Zimmerman was scheduled to die in the electric chair, the New York State Court of Claims awarded Zimmerman one million dollars, one of the largest awards for wrongful imprisonment).

21 See United States v. Lumpkin, 192 F.3d 280, 289 (2d Cir. 1999).

22 See United States v. Smith, 621 F. Supp. 2d 1207, 1221 (M.D. Ala. 2009). 
Courts have varied in their responses to the proffer of eyewitness identification expert testimony. Some courts have held that the evidence was properly excluded on the ground that eyewitness identification was not a key issue, and, therefore, the proffered expert testimony was not relevant. ${ }^{23}$ Other courts have stated that the expert testimony was not necessary because cross-examination of the eyewitness should be sufficient. ${ }^{24}$ Further, some courts have held that expert testimony might threaten the right of the jury to assess witness credibility, ${ }^{25}$ while other courts find that the jury already understands how memory works. ${ }^{26}$ Finally, Federal Rule of Evidence 403 has provided some courts with the ammunition to exclude this expert testimony on the basis that the expert might usurp the function of the jury, would lead to confusion, or would be a waste of time. ${ }^{27}$

This Comment attempts to resolve the circuit split over whether courts should admit eyewitness identification expert testimony under the Federal Rules of Evidence. This Comment considers the potential impact these experts will have on the jury, and whether, given the unreliability of eyewitness testimony, these experts are necessary. This Comment argues that experts should not be excluded on the basis of Rule 403, but rather the admission of this testimony should be left within the discretion of the trial court to determine if the expert comports with Rule 702.

\section{BACKGROUND ON EXPERTS, EYEWITNESS FLAWS, AND EYEWITNESS IDENTIFICATION EXPERTS}

"The vagaries of eyewitness identification are well-known; the annals of criminal law are rife with instances of mistaken identification." 28

Larry Fuller spent over eighteen years in prison after being wrongfully convicted of aggravated rape as the result of an erroneous identification. $^{29}$ The eyewitness first stated that the perpetrator was clean-shaven and identified Fuller's photograph in a photo-lineup (an

\footnotetext{
See, e.g., United States v. Moore, 786 F.2d 1308 (5th Cir. 1986).

See, e.g., United States v. Christophe, 833 F.2d 1296, 1299-300 (9th Cir. 1987).

See, e.g., United States v. Hall, 165 F.3d 1095, 1107 (7th Cir. 1999).

See, e.g., United States v. Daniels, 64 F.3d 311, 315 (7th Cir. 1995) (quoting United States v. Larkin, 978 F.2d 964, 971 (7th Cir. 1992)) (finding that an expert "will not aid the jury because it addresses an issue of which the jury already generally is aware, and it will not contribute to their understanding of the particular factual issues posed"); State v. Lawhorn, 762

27 United States v. Lumpkin, 192 F.3d 280, 289 (2d Cir. 1999); United States v. Kime, 99 F.3d 870, 884 (8th Cir. 1996); United States v. Curry, 977 F.2d 1042, 1052 (7th Cir. 1992).

28 United States v. Wade, 388 U.S. 218, 228 (1967).

29 The Justice PROJECT, supra note 2, at 14.
} S.W.2d 820, 823 (Mo. 1988). 
old picture taken when Fuller did not have a beard). ${ }^{30}$ The problem was, at the time of the crime, Fuller actually had a beard, directly contrasting how the eyewitness initially described the perpetrator. ${ }^{31}$ Fuller was later excluded as the rapist through advanced DNA testing methods, and Governor Rick Perry granted him a full pardon in January $2007 .^{32}$

\section{A. The Admissibility of Expert Testimony}

"Jurors who think they understand how memory works may be mistaken, and if these mistakes influence their evaluation of testimony then they may convict innocent persons. A court should not dismiss scientific knowledge about everyday subjects." ${ }^{, 33}$

The first test that determined the admissibility of expert testimony was the Frye test. In Frye v. United States ${ }^{34}$ the D.C. Circuit required that the expert not only had to have the credentials to qualify as an expert, but also had to show that the scientific theory and methodology upon which his testimony was grounded met a threshold of reliability. ${ }^{35}$ The Frye test created a "general acceptance" standard. ${ }^{36}$ The principles for admission of expert testimony at trial were formulated based on reliability and whether the scientific evidence had gained general acceptance in the particular field in which it belongs. ${ }^{37}$

Then, in 1975, the Federal Rules of Evidence were adopted. These rules led to an increasing acceptance of expert testimony generally, and Rule 702 liberalized the admissibility of expert witness testimony. ${ }^{38}$ Rule 702 provides that:

If scientific, technical, or other specialized knowledge will assist the trier of fact to understand the evidence or to determine a fact in issue, a witness qualified as an expert by knowledge, skill, experience, training, or education, may testify thereto in the form of an opinion or otherwise, if (1) the testimony is based upon sufficient facts or data, (2) the testimony is the product of reliable 
principles and methods, and (3) the witness has applied the principles and methods reliably to the facts of the case.

Rule 704 abolished the "ultimate issue" objection that blocked witnesses, both lay and expert, from testifying directly to facts that the fact-finder must determine. ${ }^{40}$ The "ultimate issue" objection was often worded as "usurping the function of the jury." vides: "Except as provided in subdivision (b), the testimony in the form of an opinion or inference otherwise admissible is not objectionable because it embraces an ultimate issue to be decided by the trier of fact." 42 The Advisory Committee Notes on Rule 704(b) rejects the "empty rhetoric" notion that some expert testimony is inadmissible because it usurps the "province of the jury."

Of course, there is a way for the judge to keep out evidence and act as "gatekeeper" if she feels as though the probative value of the evidence is substantially outweighed by the risk of unfair prejudice, waste of time, or confusion of the jury, and this is through Federal Rule of Evidence 403. ${ }^{44}$ However, Rule 403 is written in a way to favor admissibility. ${ }^{45}$ Rule 403 presumes admissibility by stating that evidence "may be excluded" if the court determines that the "probative value is substantially outweighed by the danger of unfair prejudice." ${ }^{46}$

In 1993, the United States Supreme Court acknowledged that it had moved away from the Frye test to a position that was in accordance with the Federal Rules of Evidence. ${ }^{47}$ The Supreme Court decided Daubert v. Merrell Dow Pharmaceuticals, Inc., ${ }^{48}$ which involved a suit brought by two children and their parents against a pharmaceutical manufacturer, which had allegedly caused birth defects. ${ }^{49}$ The lower courts had granted the defendant's motion for summary judg-

39 FED. R. EVID. 702.

40 Christopher B. Mueller \& Laird C. Kirkpatrick, Evidence Under the Rules: Text, CASes, And PRoblems 620 (6th ed. 2008); see also Fed. R. Evid. 704.

41 MUELLER \& KIRKPATRICK, supra note 40.

42 FED. R. EVID. 704(a).

43 United States v. Smith, 621 F. Supp. 2d 1207, 1220 (M.D. Ala. 2009).

44 The text of Federal Rules of Evidence 403 reads: "Although relevant, evidence may be excluded if its probative value is substantially outweighed by the danger of unfair prejudice, confusion of the issues, or misleading the jury, or by considerations of undue delay, waste of time, or needless presentation of cumulative evidence."

45 See FED. R. EVID. 403.

46 Id. (emphasis added); accord Paul C. Giannelli, Daubert: Interpreting the Federal Rules of Evidence, 15 CARDOZO L. REV. 1999, 2011 (1994) ("[R]ule [403] is clearly biased in favor of admissibility.").

47 Daubert v. Merrell Dow Pharm., Inc., 509 U.S. 579 (1993).

$48 \quad$ Id.

$49 \quad I d$. at 582 
ment based on the defendant's well-qualified expert's affidavit that stated that the drug did not cause birth defects; and while the plaintiffs brought forth other experts on the subject to show the opposite, the evidence was found not to meet the "general acceptance" test established in Frye. ${ }^{50}$ The Supreme Court reversed the motion to dismiss, acknowledging that "[n]othing in the text of Rule 702 establishes $\square$ general acceptance' as an absolute prerequisite to admissibility," thereby making the Federal Rules of Evidence the test to determine the admissibility of expert witnesses. ${ }^{52}$

Daubert established that it is Rule 702, and not federal common law, that governs the admissibility of expert testimony. ${ }^{53}$ This decision also rejected the "general acceptance" test established in Frye, instead incorporating the "general acceptance" requirement into considerations that courts should look to when deciding whether to admit expert testimony. ${ }^{54}$ These factors included whether the expert would testify as to "scientific knowledge," and whether the testimony would assist the trier of fact. ${ }^{55}$ The factors for the lower court to use when deciding whether the expert would testify to:

[S]cientific knowledge include whether the scientific theory has been or could be tested, whether the scientific theory has been subjected to peer review, whether accuracy rates regarding the scientific basis for the evidence are known, whether standards for application of the technique exist, and whether the theory or technique has gained general acceptance. ${ }^{56}$

These factors were not to be rigidly applied, and, in a later case, the Court stated that "the Federal Rules of Evidence allow district courts to admit a somewhat broader range of scientific testimony than would have been admissible under Frye ...."57 The Court later established that the Daubert test applies to experts in all cases. ${ }^{58}$

50 Id. at 597-98.

$51 \quad I d$. at 587 .

52 William David Gross, The Unfortunate Faith: A Solution to the Unwarranted Reliance upon Eyewitness Testimony, 5 TEX. WESLEYAN L. REV. 307, 321 (1999).

53 Hon. Robert P. Murrian, The Admissibility of Expert Eyewitness Testimony Under the Federal Rules, 29 CumB. L. ReV. 379, 380 (1999).

54 Daubert, 509 U.S. at 592.

Id. at $592-93$.

Id. at 593-94.

57 Gen. Electric Co. v. Joiner, 522 U.S. 136, 142 (1997); accord Eric K. Gerard, supra note 35 , at 34

58 Kumho Tire Co. v. Carmichael, 526 U.S. 137, 141 (1999). 
B. Flaws of Eyewitnesses

[E]yewitnesses who point their finger at innocent defendants are not liars, for they genuinely believe in the truth of their testimony. . . . The face of innocence has become the face of guilt. That's the frightening part the truly horrifying idea that our memories can be changed, inextricably altered, and that what we think we know, what we believe with all our hearts, is not necessarily the truth. ${ }^{59}$

The reliability of eyewitness identification has been questioned not only by those in the field of psychology but also by the courts. To prevent misidentifications, the Supreme Court, in Manson v. Brathwaite ${ }^{60}$ reiterated that the criteria for examining the reliability of identifications set down in Neil v. Biggers is still essential. ${ }^{61}$ The Court in Brathwaite and Biggers identified five factors that a trier of fact must consider when evaluating the accuracy of an eyewitness account. These factors include: the eyewitness' opportunity to view the criminal during the crime; the length of time in which the eyewitness got to view the criminal; the level of certainty demonstrated by the eyewitness; the accuracy of the eyewitness' description prior to identifying the criminal; and the eyewitness' attention while the crime was occurring. ${ }^{6}$ However, these instructions from the Court, as well as the due process procedure requirements and standard articulated by the Court in various cases, may not be enough as many factors influence eyewitness identification, and these factors are best discussed by an expert. $^{63}$

The Supreme Court in Brathwaite held that the lower courts may overlook highly suggestive police identification techniques used during a photo lineup if there are other reliability factors that indicate the totality of the circumstances suggest the eyewitness made the identification based on her memory of the crime. ${ }^{64}$ The problem with this allowance is that the lower courts would be dismissing what research

\footnotetext{
LOFTUS \& KETCHAM, WITNESS FOR THE DEFENSE, supra note 1, at 13.

Manson v. Brathwaite, 432 U.S. 98 (1997).

Neil v. Biggers, 409 U.S. 188 (1972).

Id. at 199-200; Brathwaite, 432 U.S. at 114.

63 Richard A. Wise et al., How to Analyze the Accuracy of Eyewitness Testimony in a Criminal Case, 42 ConN. L. REV. 435, 445-47 (2009). The Supreme Court has articulated the due process standard for eyewitness identification in Simmons v. United States, Kirby v. Illinois, Neil v. Biggers, and Manson v. Brathwaite. See Simmons v. United States, 390 U.S. 377, 384 (1968) (holding that in order to determine whether an eyewitness should be able to identify a defendant at trial, a due process test must be applied); Kirby v. Illinois, 406 U.S. 682, 691 (1972) (holding that due process "forbids a lineup that is unnecessarily suggestive and conducive to irreparable mistaken identification”); Biggers, 409 U.S. at 198-99; Brathwaite, 432 U.S. at 113-14.

64 Brathwaite, 432 U.S. at 115-16; see also Wise, supra note 63, at 448.
} 
has shown: that many other factors (other than the five proscribed by the Supreme Court in Biggers and Brathwaite) affect eyewitness identifications. ${ }^{65}$ The lower courts would ignore the fact that research has shown that at least one factor that the Supreme Court has established, the certainty of an eyewitness, is not determinative of accuracy, and, in fact, suggestive procedures can increase the certainty of an eyewitness and an eyewitness' confidence and is not at all indicative of the reliability of an identification. ${ }^{66}$ Instead, courts should allow experts to testify about factors that do influence memory and perception.

Many factors influence how an individual remembers an event. The bio-psycho-social factors that affect memory include perception, the phases of memory, and the variables that impact perception and memory, and the systemic factors. ${ }^{67}$ Memory depends on perception, and the process that goes into perception is highly selective. ${ }^{6}$

Memory is often misunderstood. Human memory does not record events in the way that a video camera would, rather memory is more selective. ${ }^{69}$ One aspect of identification often misunderstood is what is known as "weapon focus." When a weapon is involved during a crime the attention of a witness is focused on the weapon and the attention the witness is paying to the culprit's facial and physical characteristics is reduced. ${ }^{70}$ Jurors sometimes believe that presence of a weapon can increase the reliability of eyewitness identifications, ${ }^{71}$ and this sort of mistaken belief is what experts would come in to court to educate the jury on.

There are several factors that impact perception and memory. First, time is a significant factor, including the amount of time between relaying an event and the event taking place, and the rate at which an event happens. ${ }^{72}$ Second, the significance of the event and the violence that occurs during the event impacts perception. The violence level of a crime matters because, even when witnesses understand the significance of the event, the more violent the act, the lower the accuracy will be in perception and memory. ${ }^{73}$ Studies have shown

65 Wise, supra note 63 , at 449.

66 See infra note 120 and accompanying text (discussing the unreliability of an eyewitness' confidence as an indication of accuracy); see also Wise, supra note 63, at 449.

67 Henry F. Fradella, Why Judges Should Admit Expert Testimony on the Unreliability of Eyewitness Testimony, 2 FED. CTS. L. REV. 1 (2007).

68 Robert Buckhout, Psychology and Eyewitness Identification, 2 LAW \& PSYCHOL. REV. 75, 76 (1976)

69 Schmechel et al., supra note 12, at 195.

70 Id. at 196.

71 Id. at 197.

72 Fradella, supra note 67, at 17.

73 Id. at 19-20. 
that a person's ability to recall specific details of an event is worse if a witness has observed a violent event. ${ }^{74}$ Third, contrary to what is often believed, high stress levels can cause people not to pay sufficient attention and can negatively impact the ability of an individual to concentrate. $^{75}$ Stress is often believed to aid memory, when, in reality, stress actually impairs memory. ${ }^{76}$ Fourth, stereotypes can influence how a person perceives a situation, ${ }^{77}$ as well as the age and gender of a witness. $^{78}$

It is almost uncontroverted that human memory process takes place in three stages, including "perception of the event," "retention," and "retrieval of the stored information." 79 During the perception stage, also known as the acquisition stage, ${ }^{80}$ time, frequency, detail salience, and the degree of violence all affect the initial perception. ${ }^{81}$ Other factors such as stress, expectations, perceptual activity, and prior experience also affect the perception of the witness. ${ }^{82}$ Expectations can play a role in the process of memory, what someone expects to see will influence how an event is acquired and internalized. ${ }^{83}$

Next, during the retention stage, the information is still "susceptible to all forms of interference and decay." ${ }^{44}$ Factors include time, post-event information, and intervening thoughts. ${ }^{85}$ Any one of these factors can influence the way in which the eyewitness remembers the event, and can even reinforce the identification, even if it is not accurate. $^{86}$

74 Schmechel et al., supra note 12, at 197 (finding that thirty-nine percent of respondents believed that violence would make memory more reliable and thirty-three percent thought violence would have no effect at all).

75 Elizabeth F. Loftus, Ten Years in the Life of an Expert Witness, 10 LAW \& HUM. BEHAV. 241, 254-55 (1986).

76 Gross, supra note 52, at 316-17 (citing a 1998 study finding that when mice were placed in a controlled environment and stress was added in the form of a cat, the mice forgot the location of the exit, showing the effect stress has on memory).

77 Kerri L. Pickel, The Influence of Context on the "Weapon Focus" Effect, 23 LAW \& HuM. BEHAV. 299, 299-311 (1999).

78 Fradella, supra note 67 , at $* 24$ (discussing how age is an important factor, and how children usually fail to retain as many details as adults, but the "correct" information children can retain is similar to that of adults, and how gender may have some significance, as women have been shown to have a slightly higher accuracy rate in facial recognition).

79 Cindy O'Hagan, When Seeing is not Believing: The Case for Eyewitness Expert Testimony, 81 GEO. L.J. 741, 745 (1993).

80 Peter J. Cohen, How Shall They Be Known? Daubert v. Merrell Dow Pharmaceuticals and Eyewitness Identification, 16 PACE L. REV. 237, 242 (1996).

81 O'Hagan, supra note 79.

82 Id.

83 Cohen, supra note 80 , at 245-46.

84 O'Hagan, supra note 79 , at 746.

85 Id.

86 See id. 
During the retrieval stage, factors such as retrieval environment, specificity, and the wording of a question can influence what the eyewitness remembers. $^{87}$ One common trait is that when a witness is asked to recall an event they believe the event took longer than it actually did. ${ }^{88}$ Also a witness' ability to recall a violent crime is often worse than recalling a non-violent crime. ${ }^{89}$ It may be surprising that the environment in which the witness is questioned matters in the recalling of the event and how a witness is questioned in terms of the types of questions, and whether they are open-ended or not, also plays a significant role in the ability to recall. ${ }^{90}$

Other factors that have been known to lead to misidentifications include cross-racial identifications, ${ }^{91}$ the ways in which lineups are conducted, ${ }^{92}$ presence of a weapon during the crime, ${ }^{93}$ and post-

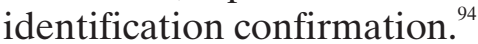

Cross-racial identifications are especially unreliable." In fact, "it is well documented that cross-racial identification is less reliable than identification of one person by another of the same race. Considerable evidence indicates that people are poorer at identifying members of another race than their own." 96 Studies have shown that when jurors are asked to compare the reliability of an identification by an eyewitness of the same race versus an eyewitness of a different race, the jurors are often "ill-informed about the inaccuracy of cross-racial identification." "97 People v. McDonald is one of the few cases overturned because the lower court did not allow an expert to testify on eyewitness testimony, when the central issue in the case was cross-

\footnotetext{
Id. at $746-47$.

Cohen, supra note 80 , at 248 .

$I d$.

$90 \quad I d$.
}

91 Studies have shown that cross-race identifications are more difficult for an eyewitness than are within-race identifications. Gary L. Wells \& Lisa E. Hasel, Eyewitness Identification: Issues in Common Knowledge and Generalization, in BEYOND COMMON SENSE: Psychological Science in the Courtroom 159, 161 (Eugene Borgida \& Susan T. Fiske eds., 2008) [hereinafter Wells \& Hasel, Eyewitness Identification].

92 Studies suggest that "failure to warn eyewitnesses prior to viewing a lineup that the actual perpetrator might not be present serves to increase the chances of a mistaken identification when the perpetrator is not in the lineup." Id.

93 Studies suggest that the presence of a weapon during a crime diminishes the ability of the eyewitness to accurately identify. Id.

94 Studies suggest that post-identification confirmation distorts an eyewitness' ability to recollect what they saw. $I d$.

95 Rutledge, supra note 14, at 211.

96 State v. Reddick, 619 A.2d 453, 467 n.1 (Conn. 1993) (Berdon, J., dissenting).

97 Schmechel et al., supra note 12, at 200. 
racial identification and experts have shown that people have difficulty identifying people of other races. ${ }^{98}$

Another reliability factor is that, often, when a show-up ${ }^{99}$ occurs and the police display a single subject, this tends to be very suggestive to the eyewitness and the Supreme Court has acknowledged the great risk of misidentification when show-ups occur, as compared to lineups. "Whereas courts have generally construed of show-ups as a form of pressure on the witness to make a positive identification, eyewitness experiments tend to show that rates of positive identification are actually lower for show-ups than for lineups."101 But when lineups are properly constructed (i.e., a lineup having at least five good fillers), ${ }^{102}$ show-ups are more likely to yield false identifications. $^{103}$

Lineup instructions can affect the identification by an eyewitness. "Telling the prospective witness to pick someone or no one based upon their personal perception and recollection of an incident is the fair technique." 104 But when an officer tells the witness to "pick the one who did it," this increases the likelihood of the witness making a choice from those presented, even if it is not accurate. ${ }^{105}$

Sequential identification, however, is one way to avoid some of the unreliability of the traditional identification. Unlike a traditional lineup, sequential identifications take place when an eyewitness views each person individually, one person at a time, and decides whether the person is in fact the culprit before viewing the next person, rather than having all members standing together and having the eyewitness identify one person out of the group. ${ }^{106}$ The benefit of sequential identifications is that the eyewitness will not make relative judgments about the individuals in the group. ${ }^{107}$ In other words, the eyewitness will not directly compare one individual to another and choose the person who looks most like the perpetrator when compared to the

98 People v. McDonald, 690 P.2d 709, 712 (Cal. 1984); see also Gross, supra note 52, at 315.

99 A show-up is an identification procedure in which a witness identifies a suspect one-onone, being the only suspect shown to the eyewitness. Amy Luria, Show Identifications: A Comprehensive Overview of the Problems and a Discussion of Necessary Changes, 86 NEB. L. REV. 515, 515-16 (2008).

100 Schmechel et al., supra note 12, at 200-01.

101 Gary L. Wells \& Deah S. Quinlivan, Suggestive Eyewitness Identification Procedures and the Supreme Court's Reliability Test in Light of Eyewitness Science: 30 Years Later, 33 LAW \& Hum. BeHAV. 1, 7 (2008).

102 Id.

103 Schmechel et al., supra note 12, at 200.

104 Gross, supra note 52, at 317-18.

105 Id.

106 Schmechel et al., supra note 12, at 202-03.

107 The Justice PROJECT, supra note 2, at 3. 
others in the group, and ultimately may pick an innocent person because the eyewitness does not feel as though there is an option that the culprit is not in the lineup. ${ }^{108}$ But jurors have been found to be unaware of the fact that sequential identifications are more accurate than lineups. ${ }^{109}$ In one study, over three-quarters mistakenly thought the reliability of line-ups was more or equal to the reliability of showups. ${ }^{110}$ To assist the jury in understanding the difference and in determining the accuracy of the identification, an expert witness would testify and simply tutor the jury so that the jury could make the ultimate credibility determination of the eyewitness. ${ }^{111}$

One other factor that some jurors are unaware can affect an eyewitness identification is the fact that the person who administers the identification procedure can influence the reliability of the eyewitness testimony. ${ }^{112}$ And, as shown in one study, a "bare majority of potential jurors" understood that having a police officer that was unaware who the suspect is could make a difference. ${ }^{113}$ Again, the potential influence of an officer's opinion is one thing that an expert could assist the jury in understanding and then the jury could make a credibility determination in the end. No matter what identification process is used, the fact that the procedure needs to be "double blind" is essential to proper identifications. ${ }^{114}$ The officer performing the identification must not know which subject is in fact the suspect so as not to (unintentionally) influence the eyewitness or interpret what the eyewitness states in such a way as to fit the suspect. ${ }^{115}$

These factors depend on psychological issues pertaining to perception and memory, causing a need for expert witnesses on this topic. As with any statistic, the numbers vary on the percentage of times in which eyewitness identifications are incorrect. Eyewitnesses identify a known wrong person in approximately twenty percent of all real criminal lineups. This means that one in five real eyewitnesses willing to give sworn testimony are wrong, and yet would put a person behind bars for a long time. ${ }^{116}$

108 Id. at 4-5.

109 Schmechel et al., supra note 12, at 202-03.

110 See id. at 203.

111 See THE Justice PROJECT, supra note 2, at 9.

112 Schmechel et al., supra note 12, at 203-04.

113 Id. at 203.

114 See The Justice Project, supra note 2.

115 Id. at 7-8.

116 Sandra Guerra Thompson, Beyond a Reasonable Doubt? Reconsidering Uncorroborated Eyewitness Identification Testimony, 41 U.C. DAVIS L. REV. 1487, 1489-90 (2008) (citing Gary L. Wells \& Elizabeth A. Olson, Eyewitness Testimony, 54 ANN. REV. PsYCHOL. 277, 291 (2003); Amy Klobuchar et al., Improving Eyewitness Identifications: Hennepin County's Blind Sequential Lineup Pilot Project, 4 CARdozo PUB. L. POL'Y \& ETHICS J. 381, 396 (2006); Tim Valentine et 
In response to the fact that eyewitness identifications are not as reliable as jurors might assume, besides expert testimony on the subject, courts have tried other methods to limit the effect of the eyewitness testimony. Some courts have relied on jury instructions as a way to lessen the weight of an eyewitness identification testimony, ${ }^{117}$ while other courts seem to think cross-examination should be enough. ${ }^{118}$ However, both of these have flaws and may have no real impact on the jury. Cross-examination, for example, might not be as effective because the eyewitness is telling what she believes is the truth, and, therefore, is likely to be believed by the jury and cross-examination loses its effectiveness. ${ }^{119}$

Special jury instructions are not effective either. Often, omission of special instructions regarding faulty eyewitness identifications is only a prejudicial error when identification is the "central issue" or "there is no corroborating evidence," leaving the matter only within the trial court's discretion. ${ }^{120}$

The confidence of an eyewitness also has an effect on whether the jury believes the identification to be accurate. ${ }^{121}$ However, a witness's confidence is not indicative of the accuracy of the identification, rather "confidence is a product of personality and social factors of which accuracy of observation is only a minor part."122 An eyewitness' confidence of her identification can fluctuate based on events after the initial identification, this has been referred to as "confidence malleability." 123 One study found that seventy-five percent of the prosecutors surveyed and fifty-six percent of the citizens surveyed incorrectly believed that confident witnesses are likely to be more accurate than those that are not confident. ${ }^{124}$ Of course, "the correlation between confidence and accuracy in eyewitness identifications is far

al., Characteristics of Eyewitness Identification that Predict the Outcome of Real Lineups, 17 APPLIED COGNITIVE PSYCHOL. 969, 973 (2003)).

117 Jennifer L. Overbeck, Beyond Admissibility: A Practical Look at the Use of Eyewitness Expert Testimony in the Federal Courts, 80 N.Y.U. L. REV. 1895, 1916 (2005) (citing United States v. Telfaire, 469 F.2d 552, 555 (D.C. Cir. 1972)).

118 Id. at 1905.

119 Id.

120 Rutledge, supra note 14, at 225 (quoting State v. Cromedy, 727 A.2d 427, 464 (N.J. 1999)); see also Peter J. Cohen, supra note 80, at 251 (discussing an experiment in which a jury was more likely to believe an eyewitness when the eyewitness provided little details and exerted confidence in his/her demeanor).

121 See Schmechel et al., supra note 12, at 198-99.

122 Id. at 199 (examining survey results and finding that "jurors have no meaningful idea of how to evaluate witness statements of confidence and are likely to substantially overestimate the reliability of a confidence witness").

123 The Justice PROJECT, supra note 2, at 5.

124 Rutledge, supra note 14, at 223 (citing Steven Penrod, Witness Confidence and Witness Accuracy: Assessing Their Forensic Relation, 1 PsychOL. PUB. POL'Y \& L. 817, 817-22 (1995)). 
lower than people would expect." ${ }^{125}$ Also, some confidence can be falsely obtained from lineup procedures where an eyewitness is unintentionally reaffirmed in their belief, once again showing the need for a double-blind lineup procedure. ${ }^{126}$ Again, this is something that an expert could address if allowed to testify during trial, and may allow the jury to understand the complexity behind identifications, and understand that confidence of an eyewitness does not translate into accuracy.

So, while expert testimony might not be a full-proof way of getting the idea of the unreliability of eyewitness across to the jury, ${ }^{127}$ it seems to be one of the more efficient methods.

\section{The Admissibility of Expert Testimony on Eyewitness Identifica- tion}

The experts that testify as to eyewitness identifications are typically psychologists specializing in human memory. ${ }^{128}$ These experts do not generally give an opinion about the accuracy of a specific identification, but instead testify as to the human memory process and describe the psychological factors that tend to affect the reliability of memory. ${ }^{129}$

The first reported decision regarding eyewitness identification expert testimony, Criglow v. State, was decided in $1931 .^{130}$ In Criglow, the defendant wanted to call an expert to give his opinion as to the recollection of two eyewitnesses. ${ }^{131}$ Neither of the two eyewitnesses had ever seen the defendant prior to the robbery, and the defendant wanted the expert to testify as to the weaknesses in eyewitness testimony. ${ }^{132}$ The trial court excluded this expert, and the Supreme Court of Arkansas affirmed. ${ }^{133}$ The court held that the question of whether the witnesses were mistaken in their identification was a question for the jury, and not an expert witness. ${ }^{134}$ The court found that because

125 Id. (quoting United States v. Stevens, 935 F.2d 1380, 1401 (3d Cir. 1991)).

126 THE JUSTICE PROJECT, supra note 2, at 8.

127 There is research indicating that when both parties produce expert testimony, jurors tend to discount all the expert testimony. See Lora M. Levett \& Margaret Bull Kovera, The Effectiveness of Opposing Expert Witnesses for Educating Jurors About Unreliable Expert Evidence, 32 LAW \& HUM. BEHAV. 363, 364-65 (2008).

128 O'Hagan, supra note 79, at 755.

129 Id. at 755-56.

130 Criglow v. State, 36 S.W.2d 400 (Ark. 1931); see also Scott Woller, Rethinking the Role of Expert Testimony Regarding the Reliability of Eyewitness Identifications in New York, 48 N.Y.L. SCH. L. REV. 323, 324 (2004).

131 Criglow, 36 S.W.2d at 401.

132 Id.

133 Id.

134 Id. 
the question put to the expert was one that "one man as well as another" might answer, it was within the realm of passing upon the credibility and weight of testimony, which the court felt should remain exclusively the jury's function. ${ }^{135}$

In 1952, a California appellate court in People v. Collier, also found that the jury's role would be usurped by the admission of expert testimony on eyewitness identifications. ${ }^{136}$ In Collier, the defendant wanted to introduce an expert, a psychology professor, to testify as to the reliability of a victim's observation of the defendant. ${ }^{137}$ The California Supreme Court held that the evidence was not within the "proper field of expert testimony" and "was a matter within the province of the jury," 138 and the expert was therefore excluded.

In 1973, the Ninth Circuit decided United States v. Amaral, a case in which the defendant was charged with two counts of bank robbery, and a significant portion of the government's case rested on identification by an eyewitness. ${ }^{139}$ The defense proffered testimony of a psychologist, who would have explained the effects of stress on perception. $^{140}$ The trial judge excluded the testimony, ruling it would be inappropriate to take from the jury the determination of the weight to be given to the eyewitness testimony. ${ }^{141}$ In this threshold federal case the Ninth Circuit excluded the expert testimony on the reliability of eyewitness identification on the basis that the unreliability of eyewitness testimony and the effects of stress on perception were not outside the common understanding of the juror and that these were not proper subjects for expert opinion testimony. ${ }^{142}$

This case set forth a four-part test for the admissibility of expert testimony, requiring that: first, the defense offer a qualified witness; second, that the expert testify on a proper subject for expert or opinion testimony on particular factor outside an ordinary person's understanding; third, that the expert testify through an analysis that is generally accepted in the scientific community; and finally, that the probative value of the testimony outweigh any unfair prejudice. ${ }^{143}$ This case became a highly influential case from the Ninth Circuit and

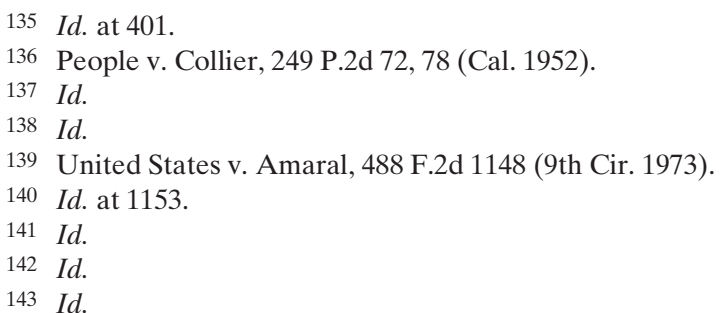


determined that the jury should decide the weight of the evidence of an eyewitness testimony, not an expert. ${ }^{14}$

Then, in 1983, the Arizona Supreme Court was one of the first to finally allow the use of expert testimony on the reliability of eyewitness identification. ${ }^{145}$ State v. Chapple became one of the first cases where a court allowed the use of expert testimony about the reliability of eyewitness testimony. ${ }^{146}$ The Arizona Supreme Court held that, under the facts, it was an abuse of discretion for the trial judge to exclude expert testimony on the reliability of eyewitness identification. ${ }^{147}$ The court followed the Amaral criteria and found that the criteria were met based upon the facts of the case. The court disagreed with other courts disallowing expert testimony on eyewitness identifications because the matter is within the common knowledge of the jury, reasoning that Rule 702 only requires an expert's testimony to assist the jury in determining an issue. ${ }^{148}$ The court found that an expert could testify to general factors that might affect the reliability of the witnesses, but the expert could not testify to the accuracy of the specific identifications the witness made. ${ }^{149}$

Federal circuit courts of appeals started to reverse district courts' decisions not to admit eyewitness experts in $1985 .{ }^{150}$ The Third Circuit Court of Appeals became the first federal circuit court to reverse a lower court's exclusion of eyewitness expert testimony and remand the case for a hearing regarding the admissibility of the expert testimony. ${ }^{151}$ United States v. Downing, however, discarded the four-part test of Amaral and substituted a three-part test. ${ }^{152}$ First, the trial judge was to balance the reliability of the scientific principles upon which the proffered testimony rests and the testimony's potential to aid the jury to reach an accurate resolution of a disputed issue, against the likelihood that the testimony might overwhelm or mislead the jury. ${ }^{153}$ Second, the defense had to show that the proffered testimony "fits" a specific problem in the identification at issue. ${ }^{154}$ Finally, even where proposed evidence might satisfy the first two requirements, the trial

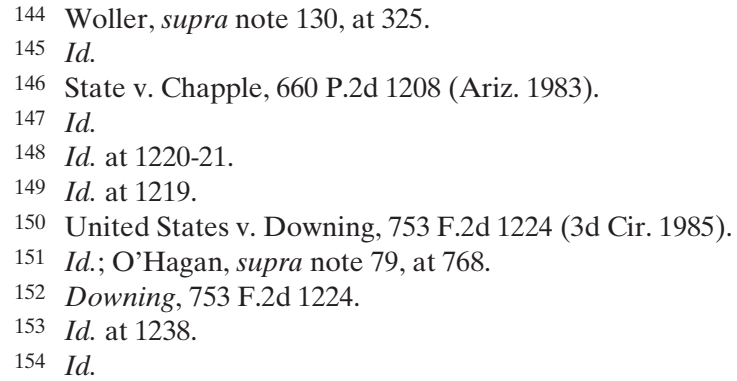


court still retains discretion under Rule $403 .{ }^{155}$ The trouble with the court's holding in Downing is that the court found it will only review a trial court decision if eyewitness testimony was the only evidence in the case, and not otherwise, thereby making this ruling not a clear solution. ${ }^{156}$

In United States v. Rincon, the Ninth Circuit Court of Appeals held that the admissibility of experts on eyewitness identifications is to be based on an individualized inquiry rather than a strict rule. ${ }^{157}$ In 1993, pre-Daubert, the Ninth Circuit agreed with the district court's decision that the defendant failed to establish the general acceptance or probative value of the subject of the expert's testimony. ${ }^{158}$ Following remand by the Supreme Court after Daubert, the Ninth Circuit remanded the case to the trial court, which once again excluded the testimony of the expert. ${ }^{159}$ The Ninth Circuit affirmed, stating that the defendant's proffered expert testimony failed to satisfy the Daubert standard. ${ }^{160}$ And although the Ninth Circuit found that the defendant failed to establish that the evidence was scientific, the court went on to decide that the evidence would help the trier of fact and was "no doubt relevant to his defense." ${ }^{161}$ The court, however, stated that the alternative means for enhancing jurors' awareness on the problems with eyewitness identifications, such as jury instructions, were available and should be used instead of expert testimony. "Given the powerful nature of expert testimony, coupled with its potential to mislead the jury, we cannot say that the district court erred in concluding that the proffered evidence would not assist the trier of fact and that it was likely to mislead the jury." 162 The court recognized that the result in this case was based on an individualized inquiry and not a strict rule regarding expert testimony on eyewitness identifications. ${ }^{163}$ Also, this idea that the jury will overwhelmingly believe the expert and put too much weight on their testimony appears to ignore evidence that jurors usually are skeptical of expert testimony. ${ }^{164}$

155 Id. at $1239-41$.

156 O'Hagan, supra note 79, at 768-69.

157 United States v. Rincon (Rincon II), 28 F.3d 921, 926 (9th Cir.), cert. denied, 513 U.S 1029 (1994).

158 United States v. Rincon (Rincon I), 984 F.2d 1003 (9th Cir.), vacated, 510 U.S. 801 (1993).

159 Rincon II, 28 F.3d at 922

160 Id. at $922-24$

161 Id. at 925.

$162 I d$. at 926.

163 Id.

164 Wise, supra note 63, at 453-54 (citing Charles PATrick EWING, TRIALs of A FORENSIC PSYCHOLOGIST: A CASEBOOK 18 (2008)). 
Overall, while some circuit courts have left the admissibility of eyewitness identification experts at the discretion of the trial courts, ${ }^{165}$ some courts state that allowing these experts to testify will undermine the confidence in all eyewitness identifications and cause a battle of experts. ${ }^{166}$ Other courts question the validity of the science behind eyewitness identifications. ${ }^{167}$ Furthermore, other courts exclude experts on the general reliability of eyewitness identifications due to the belief that this was a matter of common understanding and would not have aided the jury in determining the accuracy of the identification. ${ }^{168}$ Some courts have gone further and exclude this testimony on the basis of Rule 403 and the idea that it will mislead the jury or usurp the province of the jury.

\section{The Split on Rule 403}

That a subject is within daily experience does not mean that jurors know it correctly. A major conclusion of the social sciences is that many beliefs based on personal experience are mistaken. The lessons of social science thus may be especially valuable when jurors are sure that they understand something, for these beliefs may be hard for lawyers to overcome with mere argument and assertion. ${ }^{169}$

The Second, Seventh, and Eighth Circuits have split with the Third and Sixth Circuits over whether eyewitness identification expert testimony would violate Rule $403 .^{170}$ The Third and Sixth Circuits hold that this sort of expert opinion comports with Rule 403, whereas the Second, Seventh, and Eighth Circuits hold that the expert testimony will usurp the jury's role, and therefore is inadmissible under Rule $403 .^{171}$

The Third and Sixth Circuits have allowed experts on eyewitness identifications into evidence, finding that this sort of testimony com-

165 See, e.g., United States v. Stokes, 388 F.3d 21 (1st Cir. 2004); United States v. Welch, 368 F.3d 970 (7th Cir. 2004); Hager v. United States, 856 A.2d 1143, 1147-48 (D.C. 2004); United States v. Smith, 156 F.3d 1046, 1053 (10th Cir. 1998); United States v. Jackson, 50 F.3d 1335, 1340 (5th Cir. 1995); Parker v. State, 968 S.W.2d 592, 596-97 (Ark. 1998); Campbell v. People, 814 P.2d 1, 7 (Colo. 1991).

166 United States v. Christophe, 833 F.2d 1296, 1299-300 (9th Cir. 1987); United States v. Rincon, 28 F.3d 921, 925-26 (9th Cir. 1994).

167 United States v. Langan, 263 F.3d 613, 620-25 (6th Cir. 2001); United States v. Poole, 794 F.2d 462, 468 (9th Cir. 1986).

168 United States v. Martin, 391 F.3d 949 (8th Cir. 2004); United States v. Larkin, 978 F.2d 964, 971 (7th Cir. 1992).

169 United States v. Hall, 165 F.3d 1095, 1118 (7th Cir. 1999) (Easterbrook, J., concurring).

170 United States v. Smith, 621 F. Supp. 2d 1207, 1219 (M.D. Ala. 2009).

171 Id. at 1220. 
ports with Rule 403. The Third Circuit has held that the district court erred in its decision to exclude eyewitness testimony based on Rules 403 and 702. ${ }^{172}$ The court stated that "[s]imilar to other types of expert witnesses ... experts who apply reliable scientific expertise to juridically pertinent aspects of the human mind and body should generally, absent explicable reasons to the contrary, be welcomed by federal courts, not turned away." "173 The court held that when expert testimony of this character satisfies the reliability and fit requirements of Rule 702, and there is no countervailing rationale for excluding the evidence under Rule 403, the evidence must be admitted. ${ }^{174}$ Similarly, the Sixth Circuit has held that the trial court erred in excluding an eyewitness-identification expert under 403, specifically not violating Rule 403's prohibition against evidence that invites unjustified delay. $^{175}$

Conversely, the Second, Seventh, and Eighth Circuits have held that eyewitness identification expert testimony may be excluded under Rule 403. The Second Circuit, in United States v. Lumpkin, reasoned that eyewitness identification expert testimony might usurp the jury's role of determining witness credibility, causing jurors to be confused and misled. ${ }^{176}$

Similar to Lumpkin, the Eighth Circuit Court of Appeals, in United States $v$. Kime, held that the "district court properly recognized the very real danger that the proffered expert testimony could either confuse the jury or cause it to substitute the expert's credibility assessment for its own." ${ }^{\text {"177 }}$ One difference in this case was that the expert was going to be specific as to whether the testimony of the eyewitness was credible. $^{178}$

Finally, the Seventh Circuit Court of Appeals, in United States v. Curry, held that the district court's exclusion was proper in its exercise of discretion, whether under Rule 702 or $403 .^{179}$ The defendants were convicted for conspiracy to manufacture and possess with intent to distribute in excess of fifty kilograms of marijuana. ${ }^{180}$ On appeal the defendants raised a number of issues including that the exclusion of

172 United States v. Mathis, 264 F.3d 321, 340 (3d Cir. 2001).

173 Id. at 340.

174 Id. at 342 (citing United States v. Stevens, 935 F.2d 1380 (3d Cir. 1991)).

175 See United States v. Smithers, 212 F.3d 306 (6th Cir. 2000) (holding that eyewitness identification expert testimony did not violate Rule 403's prohibition against evidence that invites unjustified delay); United States v. Smith, 736 F.2d 1103 (6th Cir. 1984).

176 United States v. Lumpkin, 192 F.3d 280, 289 (2d Cir. 1999).

177 United States v. Kime, 99 F.3d 870, 884 (8th Cir. 1996).

178 Id. at 884.

179 United States v. Curry, 977 F.2d 1042, 1051 (7th Cir. 1992).

180 Id. 
expert testimony regarding eyewitness identification was error. ${ }^{181}$ The district court had excluded the expert testimony on the basis that the jury is "generally aware" of the unreliability of eyewitness testimony and the expert would not assist the jury under Rule 702, or it could be considered unduly confusing or a waste of time under $403 .{ }^{182}$ The Seventh Circuit also acknowledged that the Rule 702 analysis incorporates Rule $403{ }^{183}$

\section{ANALYSIS}

\section{A. Eyewitness Identifications}

"The identification of strangers is proverbially untrustworthy [and] [t]he hazards of such testimony are established by a formidable number of instances in the records of English and American trials."

In 1983, Calvin Johnson was convicted of raping a young woman despite several factors that pointed to his innocence, including him being clean-shaven and the perpetrator being described as having a full beard, the victim of another almost identical rape did not initially identify Johnson as her attacker, and Johnson had four witnesses supporting his alibi. ${ }^{185}$ Johnson received a life sentence and was not exonerated until 1999, when DNA evidence was examined and Johnson was not a match. ${ }^{18}$

Over 77,000 cases per year involve eyewitness identifications, and only 500 of those cases have expert testimony regarding the accuracy of eyewitness accounts. ${ }^{187}$ With numbers like that, it is not hard to see why eyewitness identifications are so vital to our criminal trial system and why some courts might be hesitant to allow experts to come in and explain why eyewitness identifications are not reliable and why they should not be believed. Yet, juries' acceptance of these unreliable eyewitness identifications is a leading cause, if not the leading cause, of wrongful convictions. ${ }^{188}$

To date, no court has excluded eyewitness identification from trial based solely on its unreliability. ${ }^{189}$ But even the Supreme Court has

181 Id.

182 Id. at 1051.

183 Id. at 1051 (quoting United States v. Downing, 753 F.2d 1224, 1242 (3d Cir. 1985)).

184 United States v. Wade, 388 U.S. 218, 228 (1967) (quoting Felix Frankfurter, The Case of Sacco and Vanzetti 30 (1928)).

185 The Justice PROJECT, supra note 2, at 10-12.

$186 I d$. at 12.

187 Gary Wells et al., Eyewitness Identification Procedures: Recommendations for Lineups and Photospreads, 22 LAW \& HUM. BEHAV. 603, 609 (1998).

188 Overbeck, supra note 117, at 1895-96.

189 O'Hagan, supra note 79, at 752. 
recognized that "despite its inherent unreliability, much eyewitness identification evidence has a powerful impact on juries." ${ }^{\text {"190 }}$ And other courts have recognized that "[b]ecause eyewitness testimony is such powerful stuff and can decide a case on its own strength, it can blind a jury to other exculpatory evidence or inferences."191

There is a desire for juries to believe eyewitness testimonies. "All the evidence points rather strikingly to the conclusion that there is almost nothing more convincing than a live human being who takes the stand, points a finger at the defendant, and says, $\square$ That's the one!", 192 Due to this powerful role of eyewitness testimony, courts tend to want to exclude the expert testimony that would damper such a big part of the prosecution's case. However, experts would only inform the jury of the general phenomena that affect the reliability of memory, and would help to sensitize the jurors to the effects that different factors may have on an eyewitness' ability to recount the events. $^{193}$ Some studies have shown that eyewitness experts do not make jurors skeptical but actually promote an understanding of memory works in relation to eyewitness accuracy. ${ }^{194}$

Still, if studies dating back to 1923 have concluded that eyewitness identifications are not reliable, ${ }^{195}$ the impact of these testimonies should be limited to the best of the trial court's ability.

\section{B. Expert Opinion in Courts}

In order to comport with Daubert and Rule 702, the expert's testimony must be the product of reliable principles and methods, and the witness must aid the trier of fact. The courts finding that expert opinion on eyewitness testimony does not violate Rule 403 (the Third and the Sixth Circuits) have noted that if the expert testimony comports with Rule 702 then the lower court erred in excluding it under Rule $403 .^{196}$

190 Watkins v. Sowders, 449 U.S. 341, 352 (1981) (Brennan, J., dissenting).

191 Kampshoff v. Smith, 698 F.2d 581, 587 (2d Cir. 1983).

192 Watkins, 449 U.S. at 352 (Brennan, J., dissenting) (quoting ElizABETH LofTUs, EYEWITNESS TESTIMONY 19 (1979)).

193 See Roger B. Handberg, Expert Testimony on Eyewitness Identification: A New Pair of Glasses for the Jury, 32 AM. CRIM. L. REV. 1013, 1024-27 (1995) (discussing the use of eyewitness identification experts in order to give the jury an understanding of how memory works and how to evaluate an eyewitness' credibility).

194 Id.; cf. Michael McCloskey \& Howard E. Egeth, Eyewitness Identification: What Can a Psychologist Tell a Jury?, 38 AM. PSYCHOL. 550, 552 (1983) (stating that studies have shown the possibility of expert testimony causing the jury to disregard even credible eyewitnesses).

195 See Hallisey, supra note 3, at 242.

196 See United States v. Mathis, 264 F.3d 321 (3d Cir. 2001); United States v. Smith, 736 F.2d 1103 (6th Cir. 1984). 
Rule 403 allows exclusion of evidence on grounds of prejudice, confusion, or waste of time, ${ }^{197}$ and eyewitness identification experts, in general, do not give rise to one of these reasons for exclusion. Rule 403 is written in favor of admissibility, and, as such, the assumption should be the evidence is admissible, and only in certain circumstances should evidence give rise to exclusion under Rule 403. Because the expert is there to educate the jury in the different factors that can influence how someone remembers an event, experts in eyewitness identifications do not give rise to exclusion under Rule 403 based on the risk of causing confusion or wasting time. ${ }^{198}$

One study of the influence of experts found that participants exposed to expert testimony were less likely to convict the defendant thirty-nine percent convicted - than participants who had not heard the expert testimony - fifty-eight percent convicted. ${ }^{199}$

\section{Reliability}

Mistaken identification "probably accounts for more miscarriages of justice than any other single factor." ${ }^{200}$ So, increasingly, courts have begun to allow expert testimony on the unreliability of eyewitnesses. The experts that have been allowed to testify are classically psychologists who specialize in human memory and perception. ${ }^{201}$

In the 1970s, psychological experts discovered substantial evidence that eyewitness testimony is often inaccurate. ${ }^{202}$ The experts' testimonies incorporate data that has been subjected to peer review and the methods these experts use are generally accepted, and, therefore, fit within the Daubert test. ${ }^{203}$

In cases such as United States v. Smith, when the expert on eyewitness identification has credentials such as a Ph.D. and is a professor, as well as having written articles on the topic, the expert fits with-

197 See FED. R. EVID. 403.

198 Steven I. Friedland, On Common Sense and the Evaluation of Witness Credibility, 40 CASE W. RES. L. REV. 165, 171 (1990).

199 Elizabeth F. Loftus, Impact of Expert Psychological Testimony on the Unreliability of Eyewitness Identification, 65 J. APPLIED PSYCHOL. 9 (1980).

200 United States v. Wade, 388 U.S. 218, 229 (1967).

201 O'Hagan, supra note 79, at 755.

202 Overbeck, supra note 117 , at 1895.

203 Courts have previously not permitted experts to testify on the basis of their methods being "unscientific." See, e.g., United States v. Kime, 99 F.3d 870, 883 (8th Cir. 1996) (finding that two articles on the topic of lineups did not constitute scientific knowledge within the meaning of Daubert); United States v. Brien, 59 F.3d 274, 277 (1st Cir. 1995) (affirming the inadmissibility of an expert testimony on eyewitness identification, noting that the defendant failed to provide data or literature supporting the expert's opinion). 
in the meaning of Daubert and should be permitted to testify so long as the testimony would assist the jury. ${ }^{204}$

\section{Assistance to the Jury}

Juries "tend to place great weight on eyewitness identifications, often ignoring other exculpatory evidence." 205 In United States v. Moore, the court recognized that expert testimony should be admitted "when there is no inculpatory evidence presented against the Defendant with the exception of a small number of eyewitness identification," and that "in a case in which the sole testimony is casual eyewitness identification, expert testimony regarding the accuracy of that identification is admissible and properly may be encouraged."206 The argument for eyewitness identification expert testimony begins here, with the idea that when a defendant is being prosecuted based on a few eyewitness accounts, the defendant should be allowed to bring evidence to show that eyewitness identifications are not always accurate, and further can be rather unreliable.

Many courts reject expert testimony about eyewitness identifications on the basis that the flaws of eyewitness identifications are "common knowledge" and therefore the expert would not assist the trier of fact and does not comport with Daubert. ${ }^{207}$ However, as noted in many scientific studies, jurors do not know the inherent flaws in eyewitness identification and, therefore, an expert explaining this would assist them in determining what weight to give to the evidence. $^{208}$

It is true that the common knowledge challenge survived Daubert and the expert being offered must "assist the jury." ${ }^{209}$ Courts cannot assume, however, that the average juror would be aware of the variables that experts discuss in their testimony of eyewitness reliability, as some courts argue to be the basis of exclusion of expert testimony on eyewitness reliability. ${ }^{210}$ Studies have shown that jurors do not have "common knowledge" of the unreliability of eyewitness identification and tend to misunderstand how memory works. ${ }^{211}$ Courts have recognized that "potential inaccuracies of cross-racial identifications

\footnotetext{
204 United States v. Smith, 621 F. Supp. 2d 1207, 1212-13 (M.D. Ala. 2009).

205 State v. Cromedy, 727 A.2d 457, 461 (N.J. 1999).

206 United States v. Moore, 786 F.2d 1308, 1313 (5th Cir. 1986).

207 Wells \& Hasel, Eyewitness Identification, supra note 91, at 161.

208 Id.

209 Overbeck, supra note 117 , at 1910

210 State v. Chapple, 660 P.2d 1208, 1221 (Ariz. 1983).

211 Wells \& Hasel, Eyewitness Identification, supra note 91, at 159.
} 
are not necessarily within the common knowledge of the average juror or, for that matter, the average judge." ${ }^{212}$

Some courts keep out eyewitness identification experts because the testimony is "not beyond the ken of the jurors." 213 In other words, that expert testimony on the subject will not be helpful to the jury. ${ }^{214}$ However, the helpfulness requirement in Rule 702 is a liberal standard, and a marginal improvement on the jurors' understanding is typically enough. ${ }^{215}$ Also, there is evidence to show that the information provided by experts on eyewitness identification is often "beyond the ken" of the jury, and judges as well as jurors often do not have an understanding of how memory works. ${ }^{216}$

In United States v. Smith, the District Court for the Middle District of Alabama recognized that in a case where eyewitnesses were the majority of the evidence against the defendant and the two eyewitnesses to the bank robbery conversed with each other prior to providing the testimony, an expert's testimony would be helpful and assist the trier of fact in making their determination. ${ }^{217}$

When expert testimony satisfies the reliability and fit requirements of Rule 702, and when there is no countervailing rationale for excluding the evidence under Rule 403, the evidence should be admitted. $^{218}$

3. The Issue of Rule 403

The jury's role is to weigh evidence presented and reach the truth based on that evidence. The Rules of Evidence were put into place as to enhance the truth-finding process. ${ }^{219}$ Bringing in experts to explain eyewitness identification would not deter from this truth-finding but rather enhance the jury's understanding of the truth of how memory works in order to make a credibility determination. ${ }^{220}$

But some courts have reasoned that eyewitness identification expert testimony might usurp the province of the jury in determining the

212 Smith, 621 F. Supp. 2d at 1216 (citing Commonwealth v. Zimmerman, 804 N.E.2d 336, 344 (2004) (Cordy, J., concurring)).

213 See, e.g., People v. Lee, 750 N.E.2d 63, 66-67 (N.Y. 2001).

214 See Schmechel et al., supra note 12, at 191-92; see also FED. R. EVID. 702.

215 See Schmechel et al., supra note 12, at 191.

216 See id.

217 Smith, 621 F. Supp. 2d at 1217.

218 United States v. Mathis, 264 F.3d 321, 342 (3d Cir. 2001).

219 Friedland, supra note 198, at 171-72.

220 See O'Hagan, supra note 79, at 772. 
witness' credibility and might cause confusion or mislead the jury. ${ }^{221}$ However, the other courts have, more accurately, held that eyewitness-identification expert testimony comports with Rule 403. ${ }^{222}$ "[A]n expert's opinion does not invade the province of the jury. It is merely offered as any other evidence, with the expert subject to crossexamination and the jury left to determine its weight."223 If the expert testimony comports with Rule 702, it should, by reasoning, also comport with Rule 403. "Pragmatically, the $\square$ helpfulness' analysis under Rule 702 effectively predetermines the issue [of Rule 403]. It is unlikely the trial judge will conclude that the testimony will help the jury resolve a material issue, and then decide the jurors will not be able to understand the evidence or its purpose."224

Rule 704 seems to indicate that the argument used for keeping expert testimony out under Rule 403 is in fact the type of objection that was abolished by Rule $704 .^{225}$

In United States v. Mathis, ${ }^{226}$ the court reversed the decision from the district court that excluded eyewitness testimony based on Rules 702 and 403. The court explained that eyewitness-identification experts who employ "reliable scientific expertise to jurdicially pertinent aspects of the human mind ... should ... be welcomed by federal courts."227

The Sixth Circuit has also found it improper to exclude this type of expert testimony on the basis of Rule $403 .^{228}$ In United States $v$. Smith, ${ }^{229}$ and United States v. Smithers, ${ }^{230}$ the court held that eyewitness-identification expert testimony did not violate Rule 403's prohibition against evidence that invites unjustified "delay."

The Middle District of Alabama, in United States v. Smith, speaks specifically to the point that the expert testimony would usurp the jury's role. ${ }^{231}$ The court addresses how it is "within the jury's exclusive province" to assess the credibility of one witness, but the court also

221 See, e.g., United States v. Lumpkin, 192 F.3d 280, 289 (2d Cir. 1999); United States v. Kime, 99 F.3d 870, 884 (8th Cir. 1996); United States v. Curry, 977 F.2d 1042, 1051-52 (7th Cir. 1992).

222 See, e.g., Mathis, 264 F.3d at 339-40; United States v. Smith, 736 F.2d 1103, 1107 (6th Cir. 1984).

223 State v. Marks, 647 P.2d 1292, 1299 (Kan. 1982).

224 Michael W. Mullane, The Truthsayer and the Court: Expert Testimony on Credibility, 43 ME. L. REV. 53, 112 (1991).

225 See FED. R. EVID. 704.

226264 F.3d 321 (3d Cir. 2001).

227 Id. at 340

228 United States v. Smith, 621 F. Supp. 2d 1207, 1220 (M.D. Ala. 2009).

229 United States v. Smith, 736 F.2d 1103, 1107 (6th Cir. 1984).

230 United States v. Smithers, 212 F.3d 306, 316 (6th Cir. 2000).

231 Smith, 621 F. Supp. 2d at 1220-21. 
notes how Rule 704(b) and the Advisory Committee Notes reject the notion that some expert testimony is inadmissible because it usurps the province of the jury. ${ }^{232}$ The court focuses on how the expert testimony can be helpful "and even essential, to assisting the jury in its exercise of the exclusive power to determine witness credibility." 233 The court in Smith allowed the expert to testify about eyewitness identification research and to "educate the jury about empirical evidence regarding the previously specified areas of eyewitnessidentification research," but the court did not allow him to speak specifically about the witnesses in the case before the court. ${ }^{234}$

The court concluded the discussion of the admissibility of the expert witness by stating "it is difficult to see how it could possibly be prejudicial to provide scientifically robust evidence that seeks to correct misguided intuitions and thereby prevent jurors from making common errors in judgment simply by giving them more accurate information about issues directly relevant to the case. ${ }^{235}$

Rule 403 should not be the rule used to exclude expert testimony on eyewitness identifications. There has been no showing that experts are a waste of time or going to mislead the jury. Rule 403 being used as a way to exclude experts does not allow for the defendant to bring forward relevant evidence that is important to help the jury understand the flaws of eyewitness identifications.

IV. COMMENTARY: REJECTION OF RULE 403 AS A BASIS FOR THE

EXCLUSION OF EXPERT TESTIMONY ON THE UNRELIABILITY OF

\section{EYEWITNESS IDENTIFICATIONS}

"Perhaps it is precisely because jurors do not appreciate the fallibility of eyewitness testimony that they give such testimony great weight." ${ }^{236}$

Although there is an increasing rate of eyewitness experts being admitted to testify in court, ${ }^{237}$ there are still many courts that exclude this sort of testimony on the basis of either Rule 403 or Rule 702 .

In encouraging the use of experts on eyewitness identifications, the two jurisdictions that allow expert testimony on eyewitness identi-

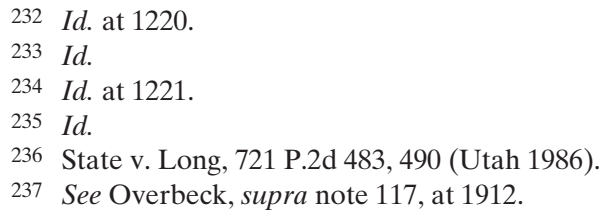


fications and find that these experts should not be kept out on the basis of Rule 403 are on the right track. ${ }^{238}$

All relevant evidence is presumed to be admissible. ${ }^{239}$ The Fifth Circuit in United States v. Moore held that the eyewitness expert was properly excluded on the ground that eyewitness identification was not the key issue, and therefore the proffered expert testimony was not relevant. ${ }^{240}$ However, Rule 401 provides that relevant evidence is any "evidence having any tendency to make the existence of any fact that is of consequence to the determination of the action more probable or less probable than it would be without the evidence," ${ }^{241}$ and Rule 402 provides, in part, that "[a]ll relevant evidence is admissible, except as otherwise provided." 242 As the Rules set forth a presumption of admissibility so long as the evidence has "any tendency" to determine the truth, ${ }^{243}$ an eyewitness expert should be admissible, even if the eyewitness identification is not the key issue. ${ }^{244}$

A 403 objection to an expert witness arises after evidence has been found to be relevant and admissible under Rule 702. But it should be noted that many 403 objections that would be made are covered in Rule 702. ${ }^{245}$ To allow an expert to testify under Rule 702 means that the court has determined that the witness is an expert, the testimony is based upon a correct application of valid scientific principles, and the evidence is helpful to the jury in assessing the credibility of the witness. ${ }^{246}$ One of the most common grounds for a 403 objection is unfair prejudice, and it is hard to see how an expert on credibility is unfairly prejudicial. ${ }^{247}$ Also, Rule 403 allows a court to exclude evidence in order to avoid misleading the jury or creating confusion. ${ }^{248}$ However, it is unlikely that a trial judge could find that the expert meets the helpfulness standard under Rule 702 and then find that that

238 See, e.g., United States v. Smith, 736 F.2d 1103 (6th Cir. 1984); United States v. Mathis, 264 F.3d 321 (3d Cir. 2001).

239 See FED. R. EVID. 402 ("All relevant evidence is admissible, except as otherwise provided by the Constitution of the United States, by Act of Congress, by these rules, or by other rules prescribed by the Supreme Court pursuant to statutory authority. Evidence which is not relevant is not admissible.").

240 See, e.g., United States v. Moore, 786 F.2d 1308 (5th Cir. 1986).

241 FED. R. EVID. 401.

242 FED. R. EVID. 402.

243 FED. R. EVID. 401.

244 See Anne Bowen Poulin, Credibility: A Fair Subject for Expert Testimony?, 59 FLA. L. REV. 991, 997-98 (2007) (arguing that "the Rules favor admissibility of relevant evidence, which logically includes expert testimony concerning credibility").

245 Rule 702 appears supra at text accompanying note 39; see also Mullane, supra note 224, at 110 .

246 See FED. R. EvID. 702.

247 Mullane, supra note 224, at 110-11.

248 See FED. R. EVID. 403. 
the jury will be mislead or confused by the evidence. ${ }^{249}$ Finally, Rule 403 allows exclusion of evidence if the evidence is a waste of time. ${ }^{250}$ However, "[t]he advisory committee's note to Rule 702 suggest that helpful expert testimony is never a waste of time." ${ }^{251}$ An expert testifying on the reliability of eyewitness identification is not a waste of time as it may help the jury decide the credibility of the identification, and lead to the jury's ultimate determination of guilt.

Some courts only allow experts if eyewitness identifications are the only evidence at trial. ${ }^{252}$ The Fifth Circuit has recognized that expert testimony on eyewitness reliability is not common knowledge and some of the psychological studies are "counterintuitive."253 In United States v. Smith, the Sixth Circuit also specifically rejected the trial court's finding that the testimony of the proffered eyewitness expert was within the common knowledge of the jury. ${ }^{254}$

The problem with limiting expert testimony to when the only evidence is eyewitness identification is that will do nothing for the trials in which other evidence is presented, and, yet, in most trials, the eyewitness identification still has the greatest weight for the jury. All eyewitness identifications present some risk of being wrong, and juries tend to rely on this evidence whether corroborated or not. ${ }^{25.5}$

The Third Circuit in United States v. Downing reversed the lower court's exclusion of an expert witness on eyewitness identifications. ${ }^{256}$ The court rejected the trial court's conclusion that the testimony was within the common knowledge of the jury and determined that the testimony "can assist the jury in reaching a correct decision" and therefore should be admitted "at least in some circumstances." court held that Rule 403 is "especially significant when there is evidence of a defendant's guilt other than eyewitness evidence."258 The problem with Downing is that the court had reserved the right for the

249 Mullane, supra note 224, at 112; see also Roger B. Handberg, Expert Testimony on Eyewitness Identification: A New Pair of Glasses for the Jury, 32 AM. CRIM. L. REV. 1013, 1032 (1995).

250 See FED. R. EVID. 403.

251 Mullane, supra note 224, at 113 (quoting the advisory committee stating that "[w]hen expert opinions are excluded, it is because they are unhelpful and therefore superfluous and a waste of time").

252 See, e.g., United States v. Moore, 786 F.2d 1308, 1313 (5th Cir. 1986) (stating that expert testimony "may be encouraged" if the only evidence against the defendant is identification evidence).

253 Id. at 1312.

254 United States v. Smith, 736 F.2d 1103, 1105-06 (6th Cir. 1984).

255 See O'Hagan, supra note 79, at 767.

256 United States v. Downing, 753 F.2d 1224 (3d Cir. 1985).

257 Id. at 1231-32.

258 Id. at 1243. 
trial court to utilize Rule 403 in order to exclude eyewitness testimony. ${ }^{259}$ The court accepted the fact that an expert's testimony may be excluded if the testimony is too general or not "sufficiently tied to the facts of the case." ${ }^{260}$ And, contrary to Downing, it should be the government who bears the burden of showing the evidence should be excluded on the basis that it is irrelevant. ${ }^{261}$

The Third Circuit in Mathis recognized that excluding expert testimony on eyewitness identification on the basis of 403 was unwarranted. ${ }^{262}$ The court found that "[w]ith respect to the District Court's concern with 'confusing and misleading the jury' and 'unfair prejudice,' we are unable to discern from these references ... . how such problems might arise." $" 263$ This court also recognized that these experts do not usurp the function of the jury. "Similar to other types of expert witnesses, who might testify about the flaws of a computerized filing system or the proper interpretation of satellites photographs, experts who apply reliable scientific expertise to juridicially pertinent aspects of the human mind and body should . . . be welcomed by federal courts." 264 As appreciated in Mathis, the experts are not there to tell the jury whether to believe the eyewitness account, but rather "to provide information that, if deemed credible, might cause the jury to evaluate [the eyewitness'] testimony in a different light."265

The jury ultimately will determine the witness's credibility in a trial, but an expert should be able to come in to assist the jury in making their ultimate credibility determination, deciding whether to believe an eyewitness' account of an event. ${ }^{266}$

Eyewitness identifications are among the most important forms of evidence presented in criminal trials and mistaken identifications appear to be the most frequent source of wrongful convictions. ${ }^{267}$ Accordingly, the defendant in a criminal case should be able to bring in

259 Id.

260 Id. at 1242.

261 Id.

262 United States v. Mathis, 264 F.3d 321 (3d Cir. 2001) (holding that the district court erred in excluding the defendant's expert testimony on the likelihood of the officer's misidentification stemming from earlier viewing of the defendant's photograph, but finding that the error was harmless given the nature of the other testimony).

263 Id. at 339.

264 Id. at 340.

265 Id.

266 See Friedland, supra note 198, at 174-75.

267 Jennifer L. Devenport et al., Eyewitness Identification Evidence, 3 PSYCHOL. PUB. POL'Y \& L. 338, 338 (1997). 
resources that are going to help him or her against this heavily weighted testimony. ${ }^{26}$

Expert testimony should be admitted if the expert comports with Rule 702. To exclude on the basis of Rule 403 seems in direct conflict with Rule 704. As Rule 704 got rid of the "usurping the province of the jury" objection, ${ }^{269}$ courts should no longer be using this as a way to exclude expert testimony on the unreliability of eyewitness identifications. The need for such eyewitness experts is because jurors should be aware of the inherent flaws in this sort of testimony and be weary, not putting the amount of weight that they normally would.

It should be noted that appellate courts recognize that trial courts are in a better position to strike a Rule 403 balancing test. ${ }^{270}$ Also, when the trial court does engage in the balancing process it articulates the rationale for its conclusion and that the conclusion "should rarely be disturbed.",271

Under the Federal Rules this sort of evidence is admissible, and if the crux of the prosecutor's case relies on an eyewitness, an expert should be allowed to come in and inform the jury on the unreliability of eyewitness identifications so that the jury can make a more informed decision when determining the credibility of the eyewitness.

There is an underlying fear that jurors will be skeptical, ${ }^{272}$ but is that not the point? Often, eyewitness testimony is not accurate, but in order to keep eyewitness testimony as a major part of trials, courts fall back on Rule 403 to exclude experts that may demystify this crucial evidence.

Case after case demonstrates how eyewitness testimony makes all the difference and defendants should be allowed to bring in relevant evidence ${ }^{273}$ including experts on eyewitness identification reliability. ${ }^{274}$

268 Another important aspect to insuring proper eyewitness identification is through documentation. Documenting the eyewitness' statement immediately after the identification can be essential to preserving the eyewitness' account of events and insuring the most accuracy as possible. See The Justice Project, supra note 2, at 7.

269 See FED. R. EvID. 704(a); see also, e.g., State v. Chapple, 660 P.2d 1208, 1219 (Ariz. 1983) ("[T]he worry about invading the province of the jury has been solved for us by the provisions of Rule $704 \ldots$ which permits opinion testimony even though it $\square$ embraces an ultimate issue."”).

270 Virgin Islands v. Pinney, 967 F.2d 912, 918 (3d Cir. 1992).

271 Id.

272 See United States v. Christophe, 833 F.2d 1296, 1300 n.1 (9th Cir. 1987) (“[P]sychologists warn that expert testimony may detrimentally affect a jury, in that jurors may be overly skeptical of an eyewitness' testimony as a result of the expert's testimony.").

273 Federal Rule of Evidence 402 provides, in part, that "[a]ll relevant evidence is admissible, except as otherwise provided," and Federal Rule of Evidence 401 provides that relevant evidence is any "evidence having any tendency to make the existence of any fact that is of consequence to the determination of the action more probable or less probable than it would be without the evidence." 
As Rule 403 is designed to favor admissibility, ${ }^{275}$ it should not be that the default is keeping out the expert testimony but that the expert testimony should be allowed in unless there is a showing that unfair prejudice substantially outweighs the probative value.

Courts fear that this sort of evidence on the unreliability of eyewitness testimony will lead to the total disbelief of eyewitnesses, thus eliminating one of the strongest forms of evidence that can be offered by a prosecutor. But " $t$ t]he hope in admitting expert testimony is for an informed jury that is more realistically skeptical of eyewitness identifications. It is impossible to know whether the admission of expert testimony will actually lead to few convictions of the innocent, but the many cases of misidentification mandate a change."276

Eyewitness identifications are too unreliable and courts should therefore allow defendants to put forward the best evidence they can to combat this heavily weighted testimony. Courts need to recognize that eyewitness expert testimony can protect against the risk of incorrect, uncorroborated eyewitness identification, and in allowing these experts to come in, protect those defendants who are incorrectly identified. Courts should recognize the importance of eyewitness experts that will assist the jurors in understanding the unreliability of eyewitness accounts, and therefore will not give undue weight to the evidence.

Other avenues of bringing about the unreliability of eyewitness identification, such as cross-examination and jury instructions, are not as effective as expert testimony, ${ }^{277}$ although some courts still insist that cross-examination should be enough to bring out the flaws in eyewitness identification. ${ }^{278}$ The problem with just using cross-examination in order to combat the eyewitness testimony is that the eyewitness believes her story to be true, and therefore is not susceptible to the usual cross-examination tactics. ${ }^{279}$

Per se exclusion of eyewitness identifications is obviously not an option. Prosecutors heavily rely on eyewitness identifications and these identifications play too large a part in the criminal justice system to get rid of them entirely. However, admitting eyewitness experts allows for the court to maintain an equal balance between the necessary eyewitness and the right of a defendant to have a fair trial. Dis-

274 Koosed, supra note 13, at 263.

275 See, e.g., United States v. Aramony, 88 F.3d 1369, 1378 (4th Cir. 1996) (recognizing that "the balance under Rule 403 should be struck in favor of admissibility").

276 O'Hagan, supra note 79, at 772.

277 Devenport, supra note 267, at 357-58.

278 See, e.g., United States v. Christophe, 833 F.2d 1296, 1299-1300 (9th Cir. 1987).

279 See Overbeck, supra note 117, at 1905. 
trict courts should follow the parameters set up by circuit courts that have encouraged expert testimony and not excluded this evidence on the basis of 403 .

\section{CONCLUSION}

" $\square$ Eyewitness identification error, usually unintentional, is the factor that is most often associated with wrongful convictions.' Yet, eyewitness testimony is the most persuasive form of evidence used by prosecutors to convict alleged criminals." 280

In over seventy percent of the first eighty-two DNA exonerations, mistaken eyewitness identification was a factor and was the leading cause of wrongful convictions ${ }^{281}$ and it has been estimated that up to eighty percent of the time juries believe eyewitnesses. ${ }^{282}$ With these numbers, criminal defendants should be able to defend themselves against wrongful accusations by eyewitnesses by having an expert educate the jury on the different factors that affect memory and perception.

Courts are moving toward a more lenient standard and, following the guidance of Rule 702 and Daubert, are allowing more experts to come in to testify on the unreliability of eyewitness identifications. ${ }^{283}$ There is a shift toward admissibility, although many courts are still excluding on the basis of Rule 702 or 403, this sort of expert testimony should be admissible if the expert demonstrates expertise, and the testimony might, if accepted by the jury, help them decide a fact at issue. ${ }^{284}$

Other methods are not enough: Cross-examination and jury instructions are inadequate when determining the inaccuracies of eyewitness identifications. ${ }^{285}$ Expert testimony is the best tool available and it is difficult to imagine that an expert appearing to testify about the inaccuracies of eyewitness identifications would substantially outweigh as to lead to this evidence being excluded. ${ }^{286}$ Therefore, Rule 403 should not be the basis for an exclusion of experts. Perception and memory complexities are not within the common knowledge of

280 Jeffrey Chinn \& Ashley Ratliff, “I Was Put Out the Door with Nothing”- Addressing the Needs of the Exonerated Under a Refugee Model, 45 CAL. W. L. REV. 405, 411 (2009).

281 Sarah Anne Mourer, Reforming Eyewitness Identification Procedures Under the Fourth Amendment, 3 Duke J. CONST. L. \& PUB. POL'Y 49, 54 (2008).

282 Id. (citing Gary L. Wells et al., Effects of Expert Psychological Advice on Human Performance in Judging the Validity of Eyewitness Testimony, 4 LAW \& HuM. BEHAV. 275, 278 (1980)).

283 See Overbeck, supra note 117, at 1912.

284 See FED. R. EVID. 702.

285 See Overbeck, supra note 117, at 1905.

286 See FED. R. EVID. 403. 
the juror, and as such, expert testimony would not be a waste of time or cause undue delay. ${ }^{287}$ These experts are not coming in to sit as the fact-finder, but rather are there to give the fact-finder more information so that they understand the complexities of memory and will not heavily rely on eyewitness identification.

While having these experts might not be a panacea for false identifications and faulty convictions, it has the capability for allowing a jury to be more discerning in their ability to weigh evidence involving eyewitness identifications.

287 See Gary L. Wells \& Lisa E. Hasel, Eyewitness Identification: Issues in Common Knowledge and Generalization, in BeyOnd COMMOn SENSE: Psychological SCIENCE IN THE Courtroom 159, 161 (Eugene Borgida \& Susan T. Fiske eds., 2008). 